Pak. j. sci. ind. res. Ser. B: biol. sci. 201154 (3) 122-125

\title{
Sulphur Supply Enhances Wheat Growth and Yield on Saline-Sodic Soil
}

\author{
Muhammad Arshadullah*, Syed Ishtiaq Hyder and Arshad Ali \\ Land Resources Research Institute, National Agricultural Research Centre, Islamabad, Pakistan
}

(received November 10, 2010; revised June 15, 2011; accepted June 20, 2011)

\begin{abstract}
The effect of different S levels (0,25, 50 and $75 \mathrm{~kg} \mathrm{~S} / \mathrm{ha})$ on growth and ionic concentration of wheat variety Inqlab-91 directly sown on saline-sodic soil $(\mathrm{ECe}=5.65 \mathrm{dS} / \mathrm{m}, \mathrm{pH}=8.57$ and $\mathrm{SAR}=17.38$ ) was evaluated in a field experiment. Treatments were arranged using randomized complete block design (RCBD) with three replications. The crop was harvested at maturity, data on tillering, plant height, spike length, number of grains/spike, 1000- grain weight and yields (grain and straw) were recorded. Na, K, Ca and $\mathrm{S}$ concentrations in grain and straw were estimated using atomic absorption spectroscopy. Tillering, number of grains/spike, 1000- grain weight and grain yield significantly $(\mathrm{p} \leq 0.05)$ increased by enhancing the $\mathrm{S}$ application. Maximum wheat yield (4.66 t/ha) was recorded when $\mathrm{S}$ was applied at $75 \mathrm{~kg} / \mathrm{ha}$, which was $43 \%$ more than the control treatment. Maximum number of tillers/plant (161) and number of grains/spike (56) were recorded with sulphur applied at $75 \mathrm{~kg} / \mathrm{ha}$. Positive correlation $(\mathrm{r}=0.85),(\mathrm{r}=0.88)$ between calcium, potassium and negative correlation $(\mathrm{r}=-0.84)$ between grain sodium content and wheat grain yield was recorded. It indicates that presence of significantly higher $\mathrm{Ca}$ and $\mathrm{K}$ contents of grain receiving $\mathrm{S}$ application might possibly help plants to attain more $\mathrm{Ca}$ and $\mathrm{K}$ and avoided sodium uptake to alleviate salinity/sodicity stress. Economical analysis showed that maximum value cost ratio $(5.5: 1)$ was achieved with the application of $25 \mathrm{~kg} \mathrm{~S} / \mathrm{ha}$.
\end{abstract}

Keywords: wheat growth, gypsum application, salt affected soil, sulphur levels

\section{Introduction}

Sulphur is a constituent of three S-containing amino acids (cistern, cystine and methionine), which are the building blocks of protein and a key ingredient in the formation of chlorophyll (Duke and Reisenaue, 1986). Without adequate $\mathrm{S}$, crops cannot reach their full potential in terms of yield or protein content (Zhao et al., 1999). Wheat plants have a lower requirement for $\mathrm{S}$ than legumes and oilseed crops (Duke and Reisenaue, 1986). Sulphur is an essential element for growth and physiological functioning of plants (De Kok et al., 2002). Sulphur improves K/Na selectivity and increases the capability of calcium ion to decrease the injurious effect of sodium ions in plants (Badr et al., 2002; Wilson et al., 2000). Wheat requires a relatively high amount of supplemental S due to incompatibility of conditions with its period of most rapid growth during early spring, when the rate of S release from soil organic matter is quite slow (Johnson, 1999). Significant yield increases of winter wheat in response to $\mathrm{S}$ additions have been reported elsewhere (McGrath and Zhao, 1995; Randall and Wrigley, 1986). Elemental S and sulphate fertilizers increase $36 \%$ wheat grain yield (Riley et al., 2000). Under sulphur deficient conditions, *Author for correspondence; E-mail: arshad_pak786@yahoo.com crop growth and yield are declined, and the produce quality is adversely affected (Schonhof et al., 2007). Since the site under investigation is deficient in $\mathrm{S}$, therefore, this study was designed to address the $\mathrm{S}$ issue.

\section{Materials and Methods}

A field experiment was conducted to study the effect of $\mathrm{S}$ on growth and yield of wheat (Var. Inqlab-91) at Malik Farm, Farooqabad, and Sheikhupura during 2009-10. Sulphur treatments were assigned using randomized complete block design (RCBD) with three replications. The $\mathrm{S}$ treatments in this study were control, $25 \mathrm{~kg} \mathrm{~S} / \mathrm{ha}, 50 \mathrm{~kg} \mathrm{~S} / \mathrm{ha}$ and $75 \mathrm{~kg} \mathrm{~S} / \mathrm{ha}$. Gypsum as a source of S was selected for application. Different S levels were applied in designated treatments having plot size of $3.5 \times 20 \mathrm{~m}$. The recommended doses of $\mathrm{N}$, $\mathrm{P}_{2} \mathrm{O}_{5}$ and $\mathrm{K}_{2} \mathrm{O}$ at 100,80 and $50 \mathrm{~kg} / \mathrm{ha}$, respectively were applied to all treatments. The crop was irrigated with tube well water throughout the growth period. All necessary plant protection measures were done whenever required. At maturity plants were harvested to record data on tillers/plant, spike length, number of grain/spike, 1000 -grain weight and straw and grain yields/plant. Plant samples were oven dried at $60{ }^{\circ} \mathrm{C}$ to a constant weight and recorded dry matter yield. Grain and straw 
samples were ground using Wiley mill. Plant samples were then digested in perchloric-nitric diacid (2:1 1N) mixture (Rhoades, 1982) to estimate $\mathrm{Na}, \mathrm{K}, \mathrm{Ca}$ and $\mathrm{Mg}$ by atomic absorption spectroscopy. Available $\mathrm{SO}_{4}-\mathrm{S}$ of soil samples was determined by the method as described by Bardesly and Lancaster (1960). The data thus obtained were analyzed using MSTATC and treatment means were separated using LSD. Tube well water applied to wheat crop had high residual sodium corbonates however, the soluble salts were present in permissible limit. The soil was saline sodic in nature. It was deficient in sulphur i.e less than 10 ppm (Ahmad et al., 1994). The physico-chemical properties of soil (Table 1) and the quality of tube well water applied to plants are given in Table 2, respectively.

\section{Results and Discussion}

Application of S to wheat crop grown on saline-sodic soil had positive influence on growth and yield of wheat (Table 3). The effect of S application on tillering, plant height, spike length, number of grain/spike, 1000 grain weight, straw and grain yield remained statistically significant. Maximum tillers (161) were recorded on plants received $75 \mathrm{~kg} \mathrm{~S} /$ ha followed by plants received 50 and $25 \mathrm{~kg} \mathrm{~S} / \mathrm{ha}$. Plant height and spike length were the highest in treatment receiving $25 \mathrm{~kg} \mathrm{~S} / \mathrm{ha}$. The highest 1000 grain weight (38 g) was recorded in treatment receiving $25 \mathrm{~kg} \mathrm{~S} /$ ha followed by 75 and $50 \mathrm{~kg} \mathrm{~S} /$ ha. High straw (10.26 tons/ha) and grain (4.66 tons/ha) yields were attained by plants treated with $75 \mathrm{~kg} \mathrm{~S} /$ ha which is $43 \%$ higher than control treatment. The $\mathrm{S}$ treatment receiving $50 \mathrm{~kg} \mathrm{~S} / \mathrm{ha}$ registered second highest grain yield (3.91 tons/ha) which is $20 \%$ higher than control treatment followed by treatments receiving $25 \mathrm{~kg} \mathrm{~S} /$ ha producing $17 \%$ higher yield as compared to control treatment. Gupta et al. (2004) reported that S application significantly enhances wheat yield and yield components. This was possibly due to increased $\mathrm{Ca}$ and $\mathrm{K}$ in soil resulted in enhancing the availability of macro and micro-nutrients for healthy plant growth.

Table 1. Physico-chemical properties of soil at MK Farm, Farooqabad

\begin{tabular}{lll}
\hline \hline Properties & Unit & Value \\
\hline $\mathrm{pH}\left(1: 1 \mathrm{H}_{2} \mathrm{O}\right)$ & & 08.57 \\
$\mathrm{ECe}(1: 1)$ & $\mathrm{dS} / \mathrm{m}$ & 05.65 \\
$\mathrm{SAR}$ & $\left(\mathrm{m} \mathrm{mole}_{\mathrm{c}} / \mathrm{L}\right)^{1 / 2}$ & 17.38 \\
$\mathrm{CaCO}_{3}$ & $\%$ & 07.00 \\
$\mathrm{OM}$ & $\%$ & 01.33 \\
$\mathrm{Sand}$ & $\%$ & 33.00 \\
$\mathrm{Silt}$ & $\%$ & 42.00 \\
$\mathrm{Clay}$ & $\%$ & 25.00 \\
$\mathrm{SO}_{4}-\mathrm{S}$ & $\mathrm{mg} / \mathrm{kg}$ & 07.26 \\
$\mathrm{Textural} \mathrm{class}(\mathrm{USDA})$ & & Loam \\
$\mathrm{pH}\left(1: 1 \mathrm{H}_{2} \mathrm{O}\right)$ after S application & & 08.10 \\
\hline \hline
\end{tabular}

Table 2. Quality of tubewell water applied to the crop

\begin{tabular}{lll}
\hline \hline Quality & Unit & Value \\
\hline $\mathrm{pH}$ & -- & 8.3 \\
$\mathrm{ECw}$ & $\mathrm{dS} / \mathrm{m}$ & 1.6 \\
$\mathrm{RSC}$ & $\mathrm{meq} / \mathrm{L}$ & 14.7 \\
$\mathrm{HCO}_{3}{ }^{-1}$ & $\mathrm{meq} / \mathrm{L}$ & 16.3 \\
\hline \hline
\end{tabular}

$\mathrm{RSC}=$ residual sodium carbonate.

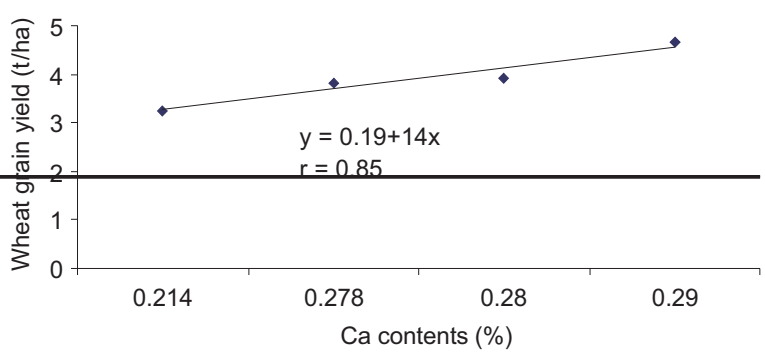

Fig. 1. Correlation between Ca content of grain and wheat grain yield.

Table 3. Effect of S on wheat growth and yield

\begin{tabular}{llllllll}
\hline \hline Treatment & $\begin{array}{l}\text { Tillers/ } \\
\text { plant }\end{array}$ & $\begin{array}{l}\text { Plant height } \\
(\mathrm{cm})\end{array}$ & $\begin{array}{l}\text { Spike length } \\
(\mathrm{cm})\end{array}$ & $\begin{array}{l}\text { Grains/ } \\
\text { spike }\end{array}$ & $\begin{array}{l}1000 \text { grain } \\
\text { weight }(\mathrm{g})\end{array}$ & $\begin{array}{l}\text { Straw yield } \\
(\mathrm{t} / \mathrm{ha})\end{array}$ & $\begin{array}{l}\text { Grain yield } \\
(\mathrm{t} / \mathrm{ha})\end{array}$ \\
\hline Control & $64^{\mathrm{d}}$ & $71.7^{\mathrm{b}}$ & $6.2^{\mathrm{c}}$ & $34^{\mathrm{b}}$ & $32^{\mathrm{b}}$ & $4.26^{\mathrm{d}}$ & $3.26^{\mathrm{c}}$ \\
$25 \mathrm{~kg} \mathrm{~S} / \mathrm{ha}$ & $127^{\mathrm{c}}$ & $97.7^{\mathrm{a}}$ & $9.7^{\mathrm{a}}$ & $54^{\mathrm{a}}$ & $38^{\mathrm{a}}$ & $7.16^{\mathrm{c}}$ & $3.82^{\mathrm{b}}$ \\
$50 \mathrm{~kg} \mathrm{~S} / \mathrm{ha}$ & $147^{\mathrm{b}}$ & $97.6^{\mathrm{a}}$ & $8.5^{\mathrm{b}}$ & $54^{\mathrm{a}}$ & $36.6^{\mathrm{a}}$ & $8.7^{\mathrm{b}}$ & $3.91^{\mathrm{b}}$ \\
$75 \mathrm{~kg} \mathrm{~S} / \mathrm{ha}$ & $161^{\mathrm{a}}$ & $94.7^{\mathrm{a}}$ & $8.33^{\mathrm{b}}$ & $56^{\mathrm{a}}$ & $37.3^{\mathrm{a}}$ & $10.26^{\mathrm{a}}$ & $4.66^{\mathrm{a}}$ \\
$\mathrm{LSD}$ & 3.86 & 3.003 & 0.6892 & 5.508 & 2.746 & 0.8382 & 0.6125 \\
\hline \hline
\end{tabular}

$\mathrm{a}, \mathrm{b}, \mathrm{c}=$ indicate statistical significant differences among treatments. 
Ionic concentration. The data presented in Table 4 indicates that the increasing concentration of $\mathrm{S}$ significantly increased $\mathrm{K}, \mathrm{Ca}$ and $\mathrm{Mg}$ and decreased $\mathrm{Na}$ contents of grains. The highest content of calcium in grain was found in plants treated with $75 \mathrm{~kg} \mathrm{~S} / \mathrm{ha}$ followed by plants treated with $50 \mathrm{~kg} \mathrm{~S} / \mathrm{ha}$. However, compared to the control treatment only, all the other treatments produced grains with significantly higher calcium content. The highest $\mathrm{K}$ content of grain was found in plants treated with $75 \mathrm{~kg} \mathrm{~S} / \mathrm{ha}$, followed by plants treated with $50 \mathrm{~kg} \mathrm{~S} / \mathrm{ha}$. Sulphur application ultimately resulted in better nutrient supply to wheat crop.

Figure 1 indicates significant positive correlation $(r=0.85)$ between calcium contents of grain and wheat

Table 4. Chemical analysis of grains for $\mathrm{Ca}, \mathrm{Na}, \mathrm{K}$ and $\mathrm{Mg}$ contents as influenced by $\mathrm{S}$ levels

\begin{tabular}{lllll}
\hline \hline S-Treatments & $\mathrm{Ca} \%$ & $\mathrm{Na} \%$ & $\mathrm{~K} \%$ & $\mathrm{Mg} \%$ \\
\hline $\mathrm{T} 1=$ Control & $0.214^{\mathrm{c}}$ & $0.217^{\mathrm{a}}$ & $0.415^{\mathrm{c}}$ & 0.134 \\
$\mathrm{~T} 2=(25 \mathrm{~kg} \mathrm{~S} / \mathrm{ha})$ & $0.278^{\mathrm{b}}$ & $0.208^{\mathrm{b}}$ & $0.434^{\mathrm{b}}$ & 0.151 \\
$\mathrm{~T} 3=(50 \mathrm{~kg} \mathrm{~S} / \mathrm{ha})$ & $0.280^{\mathrm{b}}$ & $0.185^{\mathrm{c}}$ & $0.463^{\mathrm{a}}$ & 0.142 \\
$\mathrm{~T} 4=(75 \mathrm{~kg} \mathrm{~S} / \mathrm{ha})$ & $0.290^{\mathrm{a}}$ & $0.183^{\mathrm{c}}$ & $0.469^{\mathrm{a}}$ & 0.139 \\
$\mathrm{LSD}$ & 0.006318 & 0.006318 & 0.006318 & $\mathrm{NS}$
\end{tabular}

$\overline{\mathrm{a}, \mathrm{b}, \mathrm{c}=\text { indicate statistical significant differences among }}$ treatments; NS = non significant difference among treatments. grain yield. It indicates presence of significantly higher calcium content of grain, receiving $\mathrm{S}$ application help plants to attain more calcium and $\mathrm{K}$ to avoid sodium uptake which has been an added advantage to alleviate salinity/sodicity using crop residue incorporation apart

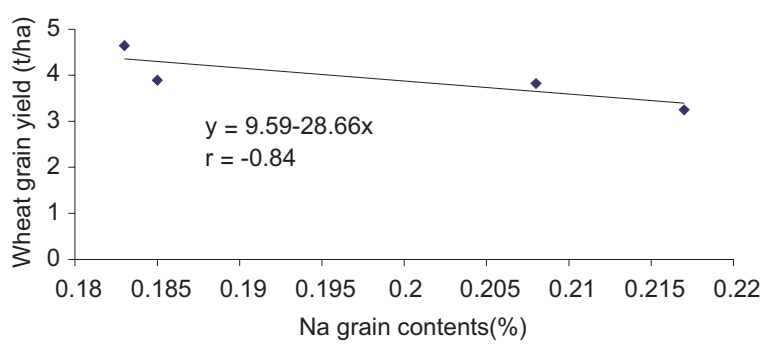

Fig. 2. Correlation between $\mathrm{Na}$ content of grain and wheat grain yield.

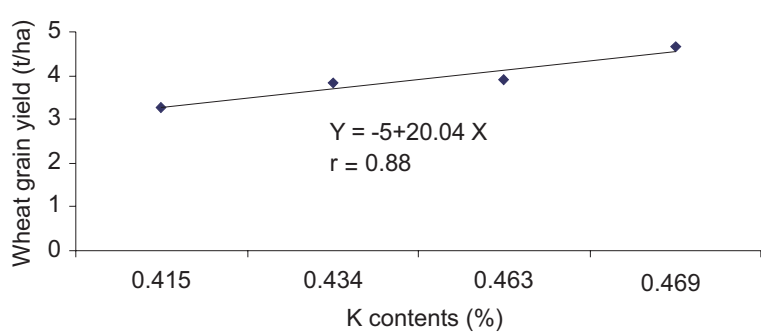

Fig. 3. Correlation between $\mathrm{K}$ content of grain and wheat grain yield.

Table 5. Economic analysis, partial budget analysis and dominance analysis of $\mathrm{S}$ on wheat crop yields

\begin{tabular}{|c|c|c|c|c|}
\hline Dose & $\begin{array}{l}\text { T1 } \\
\text { Control }\end{array}$ & $\begin{array}{l}\mathrm{T} 2 \\
25 \mathrm{~kg} \mathrm{~S} / \mathrm{ha}\end{array}$ & $\begin{array}{l}\text { T3 } \\
50 \mathrm{~kg} \mathrm{~S} / \mathrm{ha}\end{array}$ & $\begin{array}{l}\text { T4 } \\
75 \mathrm{~kg} \mathrm{~S} / \mathrm{ha}\end{array}$ \\
\hline Input cost Rs. & 0 & 2,500 & 5,000 & 7,500 \\
\hline Application Cost & - & - & - & - \\
\hline Total cost that vary Rs. & 0 & 2,500 & 5,000 & 7,500 \\
\hline Yield grain kg/ha & 3260 & 3820 & 3910 & 4660 \\
\hline Adjusted yield (10\% Low) & 2934 & 3438 & 3519 & 4194 \\
\hline Output price Rs./kg & 22 & 22 & 22 & 22 \\
\hline Straw yield kg/ha & 4260 & 7160 & 8700 & 10260 \\
\hline Adjusted yield (10\% Low) & 3834 & 6444 & 7830 & 9234 \\
\hline Output price Rs./kg & 2 & 2 & 2 & 2 \\
\hline Gross yield benefits Rs. & 72216 & 88524 & 93078 & 110736 \\
\hline Net benefits Rs. & 72216 & 86024 & 88078 & 103236 \\
\hline \multicolumn{5}{|l|}{ Dominance Analysis } \\
\hline TCV & 0 & 2500 & 5000 & 7500 \\
\hline NB & 72216 & 86024 & 88078 & 103236 \\
\hline VCR & - & $5.5: 1$ & $3.2: 1$ & $4.1: 1$ \\
\hline
\end{tabular}

$\overline{\mathrm{TCV}}=$ total cost that vary; $\mathrm{VCR}=$ value cost ratio between values of additional crop produce to the additional money spent on $\mathrm{S}$ fertilizer. 
from enhancing soil fertility and physical properties. Data in Fig. 2 indicates significant negative correlation $(\mathrm{r}=-0.84)$ indicating more sodium uptake where calcium and $\mathrm{K}$ uptake was the lowest in control treatment. Data in Fig. 3 shows significant positive correlation $(r=0.88)$ again indicating more potassium uptake as compared to control treatment. Chemical data indicates that application of sulphur combats salinity/sodicity by enhanced uptake of $\mathrm{Ca}$ and $\mathrm{K}$.

Economical analysis. Economic viability of any intervention is must for adoption in field and is the basic theme of the research. All the agronomic practices and plant protection measures were same. The input cost in treatments receiving $25 \mathrm{~kg} \mathrm{~S} / \mathrm{ha}, 50 \mathrm{~kg} \mathrm{~S} / \mathrm{ha}$ and $75 \mathrm{~kg} \mathrm{~S} /$ ha was Rs. 2500, Rs.5000 and Rs.7500, respectively. Net benefits attained by treatments receiving $25 \mathrm{~kg} \mathrm{~S} / \mathrm{ha}, 50 \mathrm{~kg} \mathrm{~S} / \mathrm{ha}$ and $75 \mathrm{~kg} \mathrm{~S} /$ hawere Rs. 86024, 88078 and 103236, respectively, which were 19, 22 and $43 \%$ higher than control treatment (Table 5). The contribution of S towards wheat yield was investigated. Data in Table 5 indicates that treatments receiving $25 \mathrm{~kg} \mathrm{~S} /$ ha attained the highest value cost ratio $(5.5: 1)$ followed by application of $75 \mathrm{~kg} \mathrm{~S} / \mathrm{ha}$ (4.1:1).

\section{Conclusion}

The present study envisages that $\mathrm{S}$ application not only enhances growth and yield of wheat on salt affected soil and it may increase the uptake of $\mathrm{Ca}$ and $\mathrm{K}$ ions and it reduces the uptake of toxic $\mathrm{Na}$ ions which helps to improve $\mathrm{K} / \mathrm{Na}$ ratio.

\section{References}

Ahmad, N., Saleem, M.T., Rashid, M., Jalil, A. 1994. Sulphur Status and Crop Response in Pakistan Soils. National Fertilizer Development Centre, Pub. No. 7/94, pp. 1-5, Planning and Development Division, Islamabad, Pakistan.

Badr, Z., Ali, A., Salim, M., Niazi, B.H. 2002. Role of sulphur for potassium/sodium ratio in sunflower under saline conditions. Helia, 25: 69-78.

Bardesly, C.E., Lancaster, J.D. 1960. Determination of reserve sulphur and soluble sulphates in soils. Soil Science Society of American Proceeding, 24: 265268.

De Kok, L.J., Castro, A., Durenkamp, M., Stuiver, C.E.E., Westerman, S., Yang, L., Stulen, I. 2002. Sulphur in Plant Physiology. Proceedings No. 500, pp. 1-26, The International Fertiliser Society, York, York, UK.

Duke, S.H., Reisenaue, H.M. 1986. Roles and requirements of sulphur in plant nutrition. In: Sulphur in Agriculture, M. A. Tabatabai (ed.), Agronomy Series No. 27, pp.124-168. Madison, WI, USA.

Gupta, V. K., Kumar, S., Singh, A. K. 2004. Yield and quality of wheat (Triticum aestivum) as influenced by sulphur nutrition and weed management. Indian Journal of Agricultural Sciences, 74: 254-256.

Johnson, J.W. 1999. Most asked agronomic questions. In: Ohio State University Extension, J.W. Johnson \& C. Hudak, (eds.), Extension Bulletin E-760-88, Columbus, OH: The Ohio State University, USA.

McGrath, S.P., Zhao., F.J. 1995. A risk assessment of sulphur deficiency in cereals using soil and atmospheric deposition data. Soil Use Management, 11: 110-114.

Randall, P.J., Wrigley, C.W. 1986. Effects of sulphur supply on the yield,composition and quality of grain from cereals, oilseeds, and legumes. Advances in Cereal Science and Technology, 8: 171-206.

Rhoades, J.D. 1982. Cation exchange capacity. In: Methods of Soil Analysis, Part 2, Chemical and Microbiological Properties. A. L. Page, R.M. Miller \& D. R. Keeney (eds.), pp. 149-158, American Society Agronomy, Inc., Madison, Wisconsin, USA.

Riley, N.G., Zhao, F.J., McGrath, S.P. 2000. Availability of different forms of sulphur fertilizers to wheat and oilseed rape. Plant and Soil, 222: 139-147.

Schonhof, I., Blankenburg, D., Muller, S., Krumbein, A. 2007. Sulfur and nitrogen supply influence growth, product appearance, and glucosinolate concentration of broccoli. Journal of Plant Nutrition and Soil Science, 170: 65-72.

Wilson, C., Lesch, S.M., Grieve, C.M. 2000. Growth stage modulates salinity tolerance of New Zealand Spinach (Tetragonia tetragonioides, Pall.) and red orach (Atriplex hortensis L.). Annals of Botany, 85: 501-509.

Zhao, F.J., Salmon, S.E., Withers, P.J.A., Monaghan, J.M., Evans, E.J., Shewry, P.R., McGrath, S.P. 1999. Variation in the bread making quality and mineralogical properties of wheat in relation to sulphur nutrition under field conditions. Journal of Cereal Science, 30: 19-31. 